\title{
Reading the Archives: The Construction of Character in Julian Barnes's Talking It Over and Love, etc.
} Arşivi Okumak: Julian Barnes'ın Seni Sevmiyorum ve Aşk, Vesaire Adlı Eserlerinde Karakter İnşası

Vanessa Guignery École Normale Supérieure de Lyon, France

\begin{abstract}
The aim of this article is to examine the meticulous way in which Julian Barnes created his characters in the diptych Talking It Over (1991) and Love, etc. (2000) through an exploration of his archives, more specifically his preliminary notes, sketches and drafts. These archival documents shed light on the protagonists' main characteristics and functions which Barnes sketched from the start. They also reveal the writer's great care in devising idiosyncratic languages for each character, which are reflective of their personalities. The paper comments in particular on the linguistic choices made by Barnes to ensure that each voice was singular. The writer was also attentive to the balance of power between the characters and the genetic dossier for the two novels reveals that he devised the female character in the trio as the "prime mover". By casting light on the living process of literary creation, this article uncovers the intricate palimpsest of Barnes's work and helps understand the writer's unique approach to characterisation.
\end{abstract}

Keywords: Julian Barnes, archives, genetic criticism, characterisation

Öz

Bu çalışma, Julian Barnes'ın iki kanatlı tabloyu andıran Seni Sevmiyorum (1991) ve Aşk, Vesaire (2000) adlı eserlerinde karakter yaratım sürecini yazarın kendi arşivi üzerinden ve özellikle yazarın notları, eskizleri ve karalamalarına odaklanarak inceler. Arşiv niteliği taşıyan bu türden dokümanlar, roman başkahramanlarının karakter özellikleri ve işlevlerinin yazar tarafından en başından itibaren nasıl oluşturulduğuna dair bilgi verir. Ayrıca, böylesi dokümanlar, yazarın her bir karakter için o karaktere özgü kişilik özelliklerini yansıtacak bir dil oluşturmada gösterdiği özeni de gözler önüne serer. Bu çalışma, Barnes'ın her bir karakterine ayrı bir ses verebilmek için yaptığı dilsel seçimlerin üzerinde özellikle durur. Ek olarak, Barnes, karakterler arasındaki güç dengesine de dikkat etmiştir ve çalışmanın konusunu oluşturan iki romanın genetik eleștirisinin açık ettiği üzere, romanlardaki ana kadın karakteri aşk üçgeninin oluşturulmasında başı çeken kişi olarak tasarlamıştır. Edebi yaratım süreçleri üzerine ışık tutan bu makale, Barnes'ın metinlerinin "palimpsest" vari özelliklerini ortaya çıkarmayı ve yazarın karakter inşası konusunda kendine özgü yaklaşımının anlaşılmasına yardımcı olmayı hedeflemektedir.

Anahtar Kelimeler: Julian Barnes, arşiv, genetik eleştiri, karakter inşası

CUJHSS, December 2020; 14/2: 141-157. DOI: 10.47777/cankujhss.848761

(C) Çankaya University ISSN 1309-6761 Printed in Ankara

Submitted: July 2, 2020; Accepted: Sep 7, 2020

ORCID\#: 0000-0003-4008-2007; vanessa.guignery@ens-lyon.fr 
In June 1989, as Julian Barnes's fifth novel $A$ History of the World in 101/2 Chapters was being published in Britain, the author was contemplating his next book whose main topic was still undecided:

I have a novel out this week, and am disguising anxiety by fretting about the next book instead. It's a toss-up between the Obsessive Love novel and the London novel - unless it turns out that one fits inside the other, as with those recipes where you stuff a duck into a goose and cook them together. (Barnes 1989)

Published two years later, Talking It Over is mostly set in London and its central theme was described by Barnes as the struggle between obsessive love and reasonable love $(1996,114)$. When asked what comes first when he starts thinking of a book, Barnes answered that the situation precedes any consideration of the characters: "I never start by making up a bunch of characters and then wonder what might happen to them. I think of a situation, an impossible dilemma, a moral or emotional quandary, and then wonder to whom it might happen and when and where" (in Cooke). The main situation of Talking It Over was inspired by a piece of gossip about two best friends in school, one of whom got married, but during the wedding his best friend fell in love with his wife and wooed her away. Barnes was told this piece of news five or six years before he started writing Talking It Over but "didn't think of it as an idea for a story, let alone a novel": "this germ of a story about wife theft [...] only became a possibility of a novel when I thought of the formal device that I then employed" (in McInerney). It is thus only after the novelist imagined the narrative strategy of juxtaposed dramatic monologues addressed to a silent interlocutor that he could start developing the story. These remarks are extremely valuable for what they reveal about the writer's creative process and the order in which composition occurs, elements which can be further analysed by perusing Barnes's papers which are stored at the Harry Ransom Humanities Center at the University of Texas in Austin.

The aim of this paper is to draw on Barnes's archives relating to Talking It Over (1991) and its sequel Love, etc. (2000) - consisting in what Jean Bellemin-Noël and other specialists of genetic criticism have called the "avant-texte" or "foretext,"1 which includes preliminary notes, sketches and drafts - in order to explore more specifically the meticulous way in which he created his characters. The authors of monographs on Barnes's work who examined the diptych Talking It Over and Love, etc. analysed his treatment of the conventional topos of the love triangle as well as the narrative strategy of monologues without any mediating narratorial voice, which accounts for the coexistence of competing versions of events and the active role granted to the

\footnotetext{
${ }^{1}$ In 1972, the French critic Jean Bellemin-Noël coined the term "avant-texte" to designate "the documents that come before a work when it is considered a text". Although the concept is not uniformly employed by geneticists, it "carries with it the assumption that the material of textual genetics is not a given but rather a critical construction elaborated in relation to a postulated terminal - so-called definitive - state of the work" (Depmann, Ferrer and Groden 8).
} 
addressee-reader (Moseley 1997, 125-144; Pateman 2002, 54-62; Guignery 2006, 73-84; Holmes 2008, 112-121; Childs 2011, 84-97). Other critics chose more specific approaches in individual papers, for example Kathleen A. Kelly who showed how the characters are controlled by "humors" and subject to neuroses which prevent them from engaging in love relations as autonomous persons, Eduardo José Valera Bravo who drew from linguistics and pragmatics to analyze the form of Oliver's "Argumentation against affairs" (Barnes 1991a, 150-51), or Merritt Moseley who explored the representations of France in Talking It Over (2011) and the poetics of the sequel (2019). This paper will adopt a different methodology based on an examination of the diptych's genetic dossier in order to shed light on the choices made by Barnes in relation to characterisation, concentrating on what he deemed essential from the start but also what he later deleted, modified or enhanced.

After examining the main characteristics and functions of the protagonists delineated in Barnes's preliminary notes, two specific aspects will be considered. First, special attention will be paid to the way the voices and personalities of the main characters were created through the use of idiosyncratic languages for each of them, with a special emphasis on Oliver. Then, the analysis will focus on the balance of power between the protagonists and show to what extent the writer's notes highlight his decision to make Gillian the prime mover in the novels.

\section{A Trio of Lovers}

In the notes jotted down during the composition of Talking It Over, Barnes described the book as an "intimate novel" (14.5), ${ }^{2}$ thus marking a difference with the wide historical and geographical range of $A$ History of the World in $10^{1 / 2}$ Chapters (1989) and the historical focus on the fall of a communist leader in his next novel, The Porcupine (1992). The intimate and domestic dimension of Talking It Over can be gauged from a page of notes with the indication "Plot" at the top (14.5), on which Barnes wrote down all the essential components of the first book (marriage, pursuit, decision time, she leaves, the false rumour, $1^{\text {st }}$ husband returns) and some of the major episodes (the second falling-in-love, the accidental meeting, on the ferry, flat opposite, her mother, $2^{\text {nd }}$ marriage, $1^{\text {st }}$ husband expatriates, $1^{\text {st }}$ husband's reflections, $2^{\text {nd }}$ marriage expatriates, the hotel room opposite). On another page, Barnes meticulously listed the particulars of "TIME - AGES - HABITATION" for each of the three main characters and summed up the book's "moral dimension" as "love overwhelms friendship" (14.5). This "love triangle" novel was therefore carefully sketched, planned and structured, as Barnes pointed out in an interview: "In Talking It Over [...] which involved a lot of intricate interweaving of voices, I tried to plan

\footnotetext{
2 Julian Barnes's papers were acquired by the Harry Ransom Center in 2002, 2006 and 2015. The archives relating to Talking It Over and Love, etc. are placed in the first acquisition identified as "Papers. 1971-2000" in the library's catalogue. Each quotation from Barnes's papers will be followed by a reference to the box and folder in which it appears. For further analysis of the archives, see Guignery 2020.
} 
100 per cent of the action. As I went on, it was coming out differently, so I ended up having only planned about 80-85 per cent of it" (in Guignery and Roberts 29-30). Ten years later, for Love, etc., whose first draft was written in longhand in a red notebook, Barnes covered eight pages with notes that detail with great precision what the novel should include and give helpful information about the characters (9.5). The genetic dossier for these two novels thus testifies to a method of composition that corresponds to what Louis Hay has called "écriture à programme" (programme writing) which relies on a pre-established plan of writing, rather than "écriture à processus" (process writing) when a writer proceeds without an entirely preconceived destination (2002, 74-5).

When focusing on the specifics of characterisation in the diptych, one should first point to the tension between the realist mode and a tendency to expose the fictional frame in a postmodernist vein. One may argue indeed that the direct address of the protagonists to the reader is a "defamiliarizing, metafictional device" which, by "pretending to collapse the ontological barrier between readers and characters," alerts us to its existence and therefore to the constructed and fictional nature of the characters (Holmes 115). On the other hand, it also clearly appears that the diptych enhances realism through the creation of verisimilar characters, what Vincent Jouve named "the illusion of person" (11): "the character, although given by the text, is always perceived in relation to a referent beyond the text" (10, my translation). This referential illusion is furthered in the diptych by the absence of a mediating narrator, thus creating what Jouve called "the illusion of autonomy": "the author, for example, refuses to keep some extra meaning for himself so as to give the illusion that he is not the creator of his characters but a mere observer" (116, my translation). Barnes readily acknowledged that he was aiming for these realistic effects: "Because the membrane between readers and characters is so thinned, [it feels] like meeting real people" (in Guignery and Roberts 86). The archives reveal further that the verisimilitude of the characters and their behaviour was a recurrent concern during composition as will be shown below.

When asked how he creates his characters, Barnes answered:

Creation of character is, like much of fiction writing, a mixture of subjective feel and objective control. Nabokov boasted that he whipped his characters like galley slaves; popular novelists sometimes boast (as if it proved them artists) that such-and-such a character 'ran away with them' or 'took on a life of his/her own.' I'm of neither school: I keep my characters on a loose rein, but a rein nonetheless. (in Guignery and Roberts 78)

The degree of looseness of the rein can be gauged from the amount of information about the characters present in the preliminary notes to Talking It Over. For each protagonist, Barnes wrote down a series of detailed functional characteristics, a relatively rare case in the archives. In an essay on his composition of Arthur \& George (2005), Barnes wrote the following: 
Novelists vary in how much, and how soon, they need to 'see' their characters. Some work 'outside in', unable to begin without a full physical presence; others (like me) tend to work 'inside out', starting from functional or moral significance. In the latter case, a character may be active in a novel without yet having a settled outline; then, at some point - even, with a minor figure, fairly late in the writing - the question of appearance needs attending to. Hair colour? Eyes? Stooping or erect of carriage? And so on. (Barnes 2007, 289)

This process is substantiated by the archives on Talking It Over as Barnes's early notes contain indications of the characters' functional significance but none about their physical appearance. Thus, he saw Gillian as "at first quiet, someone who knows her own mind but doesn't impose it, sensible, a mediator; as book goes on, becomes stronger, the organiser, etc." and added: "What if she doesn't say much at first? Then later starts talking" (14.5). The evolution suggested here is confirmed in Talking It Over, where Gillian's monologues cover half a page to a little more than a page in the first three chapters while Stuart's and Oliver's each occupy six to eight pages. From Chapter Six however, speech is more evenly balanced with Gillian talking more and confiding more in the reader.

Twice in his notes, Barnes refers to how Stuart and Oliver see Gillian:

? S\&O listing their views of G's qualities

1) practical reliable punctual

2) artistic romantic impulsive (14.5)

These two different interpretations probably reveal as much about the two men as they do about Gillian who may therefore wonder who she really is: "if two such different people as Stuart and Oliver can both fall in love with me, what sort of me is it? And what sort of me falls in love first with Stuart and then with Oliver? The same one, a different one?" (1991a, 174). In an early draft, these interrogations were followed by a paragraph which included the adjectives found in Barnes's notes:

Stuart liked my practical side. He liked me being efficient and punctual. I think that what he most admired about my restoration work was that I sent out my invoices on time. Whereas Oliver goes for what he calls my 'artistic, romantic and impulsive' nature, which is perhaps not too surprising as without it I wouldn't have fallen in love with him.

But the point is, I'm not going to swap one interpretation of me for another. (14.5)

This passage was removed from the final typescript, maybe because these external interpretations of Gillian run counter to her self-definition as an autonomous being. While Gillian's qualifications as "artistic, romantic and impulsive" do not appear in Talking It Over, ${ }^{3}$ these adjectives are employed by

3 In Love, etc., Gillian's assistant Ellie describes Gillian as "Human as well as artistic" (2000, 43). 
Oliver to describe himself as a "classical humanist of artistic bent and romantic nature" (1991a, 159). Stuart, for his part, uses two of the adjectives that appeared in Barnes's notes and early draft to qualify Gillian at the end of the novel: "Basically, she's a very practical, efficient person" (1991a, 262). The first adjective is one Gillian herself frequently uses, especially in conjunction with happiness: "You've got to be practical in these matters" (1991a, 173), "You have to be happy and practical" (1991a, 248), "I said you can be happy but you have to be practical as well" (1991a, 249), "I was just trying to be practical" (1991a, 254). In Barnes's notes for Love, etc., he wrote about Gillian: "Living $\mathrm{w}$ [ith] Ol[iver] has of necessity emphasized her practical side, wh.[ich] she at first is contented with, but increasingly resents". He also noted that she was "pragmatic" and "practical about love" (9.5), which is confirmed by her definition of love: "True love is solid love, day-to-day love, reliable love" (2000, 172). Barnes finally wrote down how Gillian should feel at the end of Love, etc.: "Gillian settling for a practical solution (for her children), half-deceiving herself that it's all a sort of love story, but at the same time thinking her emotional life is now over" (9.5). An early draft included sentences reflecting this pragmatism, which were removed from the final version: "I live for my children. I'm in my early forties and believe that most of my life is over. That's not self-pity, it's practical thinking" (9.6).

While Gillian was thus thought of from the start as a practical woman and Barnes made sure to use that adjective regularly in the novels to pithily encapsulate her temperament, Stuart and Oliver were given divergent personalities as well as names that were relatively ordinary but reflected their respective natures. In The Rise of the Novel, Ian Watt points out that eighteenthcentury novelists chose to give their protagonists ordinary realistic names (rather than "characteristic" names) which "sound authentic and are yet suited to the personalities of the bearers" (19) so as to make their existence credible. In his early notes, Barnes listed Donald and Gordon as other possible names for Stuart, but these probably evoked an older generation (Gordon was eventually used as the name of Stuart's father-in-law). The three names are nevertheless all fairly common and in Talking It Over, Oliver notes that he finds the name Stuart "really boring" (1991a, 12). In preliminary notes, Barnes thought of Martin as a possible name for Oliver whose first name is actually Nigel (1991a, 5, 13). ${ }^{4}$ The name Martin may have evoked Barnes's friend Martin Amis whose third novel Success (1978) presents the dramatic monologues of two male characters of contrasting personalities whose roles and situations are gradually reversed, which led several critics to underline thematic and narrative parallels with Talking It Over (Buchan 25-26, Hateley, Holmes 113).

When planning Talking It Over, Barnes listed the following characteristics for Stuart: "literal, foursquare, prosaic - undervalues self - dogged - mediumflier/banker can only get from A to B via a1 a2 a3 and a4, and tells you about

\footnotetext{
${ }^{4}$ Oliver got rid of Nigel because he judged the name inappropriate: “you can't go through the whole of your life being called Nigel, can you? You can't even go through a whole book being called Nigel" (1991a, 13).
} 
it"; "Stolid, English, pinstriped in mind, decent, thinks in near-clichés"; "he must be a brooder, a wanting-to-get-it-straight-er" (14.5). These specificities of a placid and unimaginative but also essentially vulnerable protagonist are indeed to be found in Talking It Over, but in the sequel, Love, etc., Stuart is "coming back for revenge," as indicated in Barnes's notes, and is therefore "much more Machiavellian / less innocent this time" (9.5).

Stuart's characterisation gains strength from his opposition to Oliver. This is emblematized by a contrast between doing and being, action and essence, which Barnes included in his notebook for Love, etc. (but not in the final book): "Stuart: People either decide to do something or be something. Oliver's happy just to be something / Oliver: You only decide to do something (as S puts it) if you haven't got anything to be" (9.5). The two men's opposing views on this are reflected in their relation to love and money, one of the central metaphors in both books which has been examined by several critics (Moseley 1997, 13233; Pateman 55-58; Childs 93) and which Barnes developed extensively in his preliminary notes. For instance, he wrote about Stuart: "He's the Thatcherite / - something in city / - but in love is idealistic, uncapitalistic," and about Oliver: "He's the liberal / green / artistic / - but in love, Thatcherite" (14.5).

Oliver is the most flamboyant and loquacious character. Hermione Lee, who has been reading and commenting on the drafts of all of Barnes's books since Before She Met Me (1982), remarked, after reading one quarter of a draft of Talking It Over: “By this page I 'suddenly' feel I can't bear to listen to 0. any more" and then "Everything about 0 . is completely insufferable. But I suppose by now I'm supposed to be cross" (14.5). Oliver is indeed meant to exasperate the reader and in a letter to a friend of 24 June 1999 as he was writing Love, etc., Barnes described him as "[h]ighly-strung, intelligent, irritating," speaking in "irritatingly grand words" (9.6). When planning Talking It Over, the novelist summed up Oliver's characteristics as "extravagant - overvalues self - no money - baroque, macaronic language," "hyper, [...] intense, moody, pretentious". He also wrote:

his psychology:

Only knows what he wants when someone else has it

Falls in love as she comes out of the wedding (14.5)

This psychology corresponds to René Girard's concept of mimetic desire, according to which one subject (Oliver) reaches for the same object of desire (Gillian) as another (Stuart) who becomes the "mediator" or "model" whose desires are imitated, and is therefore a rival. Eric Berlatsky, drawing from Eve Kosofsky Sedgwick's analysis of male homosocial desire, offers a different and interesting interpretation of the triangle when, based on Val's claim that "Oliver is queer for Stuart" (1991a, 183), he argues that "because Oliver's 'queer' desire for Stuart cannot be expressed, Gillian serves as a mediator, an object through which inappropriate same-sex desire may be triangulated" (179). Oliver's suspected homosexuality occupied more space in the early drafts of Talking It Over and was first voiced by Stuart: "I've had another thought. It's a bit silly, especially after I've known him all these years. But I 
wonder ... I wonder if Oliver's by any chance homosexual" (14.6). This and a further embarrassed elaboration by Stuart ${ }^{5}$ were removed maybe because, as noted by Berlatsky, Oliver's repressed homosexuality (also referred to in 1991a, 187-190, 217) was so obvious that it did not "require hermeneutic inquiry" (Berlatsky 180).

Barnes's extensive notes on the protagonists' psychology, taken before and after drafting Talking It Over, exceed indications on plot, thereby pointing to the great care with which he drew his characters. He was also particularly attentive to the creation of an idiosyncratic style for each character, which would mirror and reveal their personality.

\section{Character Construction through Their Idiolect}

Barnes's "selection and balance of three dissimilar styles of disclosure" has been repeatedly praised by reviewers (Imlah 19). Several critics referred to Mikhail Bakhtin's concept of polyphony to point to the plurality of voices and the way in which each voice becomes readily recognizable thanks to a specific vocabulary, syntax and rhythm (Hamilton; Guignery 2006, 75-76). These different styles also signal distinct perspectives on the world as noted by Bakhtin for whom the hybridized languages used by speakers offer "forms for conceptualizing the world in words, specific world views, each characterized by its own objects, meanings and values" $(1981,191)$.

One may take as an example of the diversity of styles and world views present in Talking It Over the episode when Oliver greets Stuart and Gillian at the airport after their return from a vacation in Crete. As recounted by Stuart, Gillian fetched a defective trolley: "when she tried to push she found out she'd got a trolley with a wonky wheel. It wouldn't go in a straight line and kept squeaking" (1991a, 68). This ominous metaphor acts as an efficient proleptic hint of the derailing of Gillian and Stuart's marriage, and the way in which the incident is told by the three characters points to differences in style which are revealing of their personalities. In his monologue, Stuart notes that he offered to take hold of the trolley: "I'd joined in trying to control the thing by now as Gillian found she couldn't manage curves on her own" (1991a, 68). ${ }^{6}$ Oliver, who has not seen Gillian picking the trolley but only Stuart pushing it, holds his pitiful friend responsible for the irregular trajectory of the vehicle (and metaphorically of the marriage): "Stuart had typically picked a trolley with one

\footnotetext{
5 “Don't misunderstand me. I wouldn't disapprove if Oliver turned out to be gay. If that's the case, then that's the case. I haven't any 'evidence' as they say, but then what is evidence? A dominant mother, a weak father? A dominant father, a weak mother? Two normal parents? There simply aren't any patterns, from how I understand it. You just are one. Do you think that makes it harder or easier? At least in the old days when it was your parents' fault you had someone to blame, if you wanted to. I'm getting confused. I suppose I just mean you are what you are, you can't help who it is you love. Not, as I say, that I've any 'evidence', and not, as I say, that I'd mind if I had" (14.5).

${ }^{6}$ An earlier draft showed Stuart as more assertive and dominating in his efforts at controlling the situation: "I'd taken over the pushing" (14.6) was later replaced by the softer "joined" and "trying".
} 
locked wheel, and he emerged from the tender scrutiny of the douaniers in a comic curve, his uncertain course hymned by Gillian's indulgent laughter and his trolley's maundering squeak" (1991a, 65). Gillian does not mention the incident of the trolley but innocently refers to her and Stuart's cheerfulness: "the two of us are having a laugh because we're safely back" (1991a, 76).

Such differing accounts are not only emblematic of the narrative mode Barnes chose for the novel, which allows each character to give their own version of what happened, but they also reveal each speaker's distinct style. Stuart uses bland and unspecific vocabulary ("the thing") and remains unaware of the double meaning of what he is describing; Oliver indulges in a flurry of adjectives and the pedantic use of a foreign word; Gillian's language is straightforward and without flourish. At the time of composition of Talking It Over, Barnes was aware of the necessity to give Gillian a specific voice in spite of her initial reticence and her insistence on being "an ordinary, private person" (1991a, 7). He was also careful not to let her take on the characteristics of other voices. For instance, in an early draft, when Gillian reports her mother's outrage at her daughter's decision to get married twice in the same dress, she numbers the various reasons why her mother finds the idea offensive: "It offended against 1. Good taste. 2. Good manners. 3. Good dress sense. 4. The Church. 5. Everyone present at both ceremonies (though mainly her). 6. Fate. 7. Luck. 8. World history. And so on" (14.6). Barnes wrote in the margin: "would G use numbers?" and realizing that this did not correspond to her type of voice but to Oliver's, ${ }^{7}$ he deleted the numbers (and the capital letters), replacing the full stops with commas (1991a, 197-98).

In a similar way, Barnes paid attention to the consistency of Stuart's monologues, in which short, simple and stable sentences reflect his attachment to clear facts and his disinclination for pretentious embellishments. When Martin Amis read the proofs of Talking It Over, he wondered about the use of a French word in one of Stuart's monologues: "wd S use French?" (15.1). For the published version, Barnes replaced "Find a little auberge" by "Find a little hotel" (1991a, 100) as foreign words are reserved for Oliver while Stuart is more typically English and monolingual, favouring commonplace words. Similarly, Hermione Lee drew attention to a passage when Stuart reports a conversation with Oliver who told him: "Well, at least he dealt you a tranche de bonheur" (1991a, 20). In the original draft, the conversation stopped there and Stuart simply resumed his monologue. Lee commented: “Surely Stu wouldn't 'get' 'tranche de bonheur'?" (14.5). Barnes took her remark into account as he added: “'A wotsit?' I asked, playing Dumb Stu. He smiled his smile, playing Sophisticated Ollie" (1991a, 20). Stuart's awareness of the distribution of roles,

\footnotetext{
7 Oliver uses numbers in his "Argumentation against affairs" (1991a, 150-51) and when referring to erroneous interpretations of his meeting with Val $(1991 \mathrm{a}, 186)$, and letters when he gives the reasons why Stuart always buys a return ticket to the airport (1991a, 78). Gordon (Mme Wyatt's husband) also includes numbers to convey "Points to make re the case of Gordon Wyatt" (1991a, 235-36). In Love, etc., Oliver uses numbers again in his "Argumentation, per et contra" contraceptive methods (2000, 108-09).
} 
underlined by the use of capital letters, reveals that he is less "dumb" than he pretends to be, as Love, etc. will confirm.

The voice which required the greatest virtuosity was Oliver's with its highlycoloured vocabulary and convoluted syntax, and its fondness for similes, metaphors, foreign words, parody, irony and cultural references. ${ }^{8}$ Oliver's voice is idiosyncratic and not, contrary to what James Wood suggested, "recognisably Barnes's voice" (26). ${ }^{9}$ In his notes on Talking It Over, the author singled out a word and asked: "is it Ollieish?" (14.5). He also wrote down some of the rare adjectives Oliver was supposed to use as part of his idiolect:

Oliver's vocabulary

inspissated oleaginous crepuscular

steatapigeous [sic] / callipygous (14.5)

The adjectives "inspissated" (1991a, 193)10 - a medical term for a substance which has become thick and is here applied to Oliver after he has fallen in love with Gillian - and "oleaginous" (1991a, 11) - a reference to the unctuous registrar at the wedding - appear only once in Talking It Over. On the other hand, "crepuscular" is used nine times (1991a, 11, 26, 40, 65, 101, 193, 194, 208,251 ) and variously applies to the registrar at the wedding, literal or metaphorical places - as for instance, Stuart bursting out of "his crepuscular oubliette of unnoticeability" (1991a, 26) - or Olivier's spirit or mood. When Martin Amis read the proofs of Barnes's books, he sometimes pointed out repetitions of the same word close to each other, which led Barnes to look for a synonym. After the third occurrence of "crepuscular" in Talking It Over (1991a, 40), Amis wrote in the margin: "Ol is keen on this word" and after the fourth (1991a, 65): "ok" (15.1). When Oliver shows his awareness of his linguistic mannerism - "I also hate the word crepuscular, I think I'll stop using it for a bit" (1991a, 101) - Amis wrote "aha!" (15.1). However, ninety pages later, Oliver falls back on his old habit and comments on his lapse: "And yes, I do know I've just said crepuscular again" (1991a, 194). This latest comment was only added at a later stage on the printer's typescript with final corrections (15.3) and offers a humorous moment of self-reflexivity.

\footnotetext{
${ }^{8}$ Moseley disagrees with reviewers who find Oliver's use of language "sophisticated" and prefers the term "[c]amp" $(2011,76)$. He describes his voice as "foppish, learned, showy, precious" $(1997,141)$.

9 Like Wood, Michael Levenson believes that Oliver's habit to "scatter bons mots like sunflower seed" (1991a, 239) is "Barnes's own verbal reflex" (Levenson 44) and Zoë Heller notes that "Oliver is the most obvious inheritor of the author's linguistic manners" (28). Moseley, for his part, insists that Barnes does not write the way Oliver speaks: Barnes "is neither so determined to show off his French nor so effortful in his own cleverness" (2011, 76).

10 In his unpublished Literary Guide to Oxford written in the 1970s, Barnes records an anecdote involving T.E. Lawrence: "Returning from London one evening, he was met at the gate of the college by Professor Edgeworth, a Fellow renowned for his avoidance of normal conversational English, and his reliance, wherever possible, on a pedantic turn of phrase. 'Was it,' enquired Edgeworth, 'very caliginous in the Metropolis?' 'Somewhat caliginous,' replied Lawrence brightly, 'but not altogether inspissated'” $(8.6,3)$.
} 
In 1991 (the year Talking It Over was published), Barnes contributed a short text for the letter "U" in Hockney's Alphabet, in which he and some friends look for "the most sinister word in the English language" and the adjectives Barnes selected were "crepuscular, curdled, inspissated, fetid" (Barnes 1991b). In November 1994, when writing the preface to his collection of essays, Letters from London, Barnes referred to the meticulous editing work of Charles McGrath (nicknamed Chip) at the New Yorker: "Chip picked on an adjective I'd used, one of those words like, say, crepuscular or inspissated, which don't form part of your core vocabulary but which you reach for from time to time. 'You've used crepuscular before,' said Chip" (1995, xiii). While Barnes adamantly protested he had not used it before, "Chip" pointed out that the word had appeared in a piece nine months previously and therefore had to be excised.

In Talking It Over and Love, etc., these polysyllabic and rare words need to be repeated as they form part of Oliver's flamboyant characterisation and verbal pyrotechnics. Next to "crepuscular," his other favourite word is "steatopygous," which appears six times in Talking It Over to refer to Stuart's voluminous buttocks $(1991 \mathrm{a}, 23,44,59,135,202,247)$ and has thus been preferred to "callipygous," a term which, unlike "steatopygous," evokes shapely and attractive curves. In Love, etc., the adjectives "steatopygous" and "crepuscular" - the most emblematic of Oliver's style - recur as early as Oliver's second monologue: "O narcoleptic and steatopygous Stuart, he of the crepuscular understanding" $(2000,12)$ and again close to each other in Chapter Nine to refer to Stuart: "Steatopygous One" $(2000,93)$, "back to his crepuscular wankpit" $(2000,94) .{ }^{11}$ At a later stage of composition of Talking It Over (probably after completing the first draft), Barnes wrote on other pages of notes:

$$
\begin{aligned}
& \text { Oliver words crepuscular, febrifuge, mogadonic } \\
& \text { mean person - major nickelfucker } \\
& \text { reuse mogadonic / poo-scared } \\
& \text { febrifuge } 81,+269 \text { - \& somewhere else? (14.5) }
\end{aligned}
$$

The adjective "mogadonic" - Mogadon is the trademark for a sleeping pill appears twice, first to refer to Stuart's self-satisfaction at his wedding (1991a, 11 ) - the adjective was only added fairly late on the printer's typescript (15.2) - and then to Oliver's lethargic mood when having his friends over for dinner (1991a, 115). In a similar way, "poo-scared" is used four times in Talking It Over $(1991 \mathrm{a}, 47,89,115,251)$ - the first three referring to Oliver himself - but only appeared once in the first drafts $(1991 \mathrm{a}, 115)$ while the three other occurrences were added at a later stage (15.2), probably because Barnes reminded himself to "reuse" the adjective so as to make Oliver's mannerisms (even for colloquial terms) more systematic. The word is included twice in echoing hyperbolic lists of adjectives when Oliver realizes he is in love with Gillian - "I'm amazed, I'm overawed, I'm poo-scared, I'm mega-fuckstruck" (1991a, 47) - and when he first tells Gillian he loves her: "I'm joyed, I'm awed,

11 The adjective "crepuscular" is used twice more to refer to places $(2000,137,151)$. 
I'm poo-scared, I'm mega-fuckstruck" (1991a, 89). The repetition of the same adjectives and syntactical construction within only forty pages draws the reader's attention to a conspicuous trait of Oliver's idiosyncratic voice which can cover the whole spectrum from pedantic, florid and exotic to crude and unrefined.

As for the noun "febrifuge" $(1991 \mathrm{a}, 79,87,264)$ - a medicine meant to reduce fever - and the expression "major nickelfucker" $(1991 a, 78,122,146)$ - to refer to a stingy person - they both appear three times in Talking It Over, and the latest expression recurs twice in Love, etc. $(2000,137,178)$, but the first and third occurrences of "febrifuge" and all occurrences of "major nickelfucker" were only added on the printer's copy (15.3). Barnes's notes about Oliver's vocabulary and his late additions reveal how meticulous he was in the creation of his character's polymorphous voice and how carefully he gauged the number of times Oliver would have to repeat the same words. On the typescript for the printer (therefore at a late stage), Barnes added in red pen two other memorable expressions to be repeated by Oliver - "rumpy pumpy" (1991a, 28, 111, 185, 217) and "mucker"/ "ex-mucker" (1991a, 26, 28, 202) which did not appear on the first drafts. These late additions suggest that Barnes wished to make Oliver's linguistic mannerisms an even more prominent trait of his character.

Such repetitions within Talking It Over (as well as in Love, etc.) seem to indicate that Oliver is stagnating as he is sticking to the sparky role he has assumed for himself, without any hint of a major evolution despite his change of marital situation. ${ }^{12}$ In his notes for the first novel, Barnes wrote: “Ollie doesn't change the other 2 do," and he gave more detail about these changes:

$$
\begin{aligned}
& S \text { changes - disillusionment } \\
& \text { G changes - stronger } \\
& \text { O remains the same (14.5) }
\end{aligned}
$$

When writing down notes on the sequel, Love, etc., ten years later, Barnes wondered: "So what has happened in the last 10 yrs, morally/character-wise?". He noted that Oliver had gone downwards "a) economically b) professionally c) emotionally d) parentally":

a career of failure - some hard luck - now more or less supported by Gillian - reaching the 'last-chance' stage. In his early 30s, he was passing for being a 20s flamboyant chancer. Now cracks showing: can you still be this at 40 ? Is he not so verbally flash as he used to be? [...] Also, he's stopped flirtatious affairs, so feels virtuous: why doesn't he get a better reward? (9.5)

Oliver's transformation in the sequel leads to his collapse but he does not seem to be less "verbally flash". Stuart has become stronger and is more "cut \& dried": "knows self better - or is more hardened - doesn't seek to please others

12 In Talking It Over, Oliver nevertheless evolves in certain areas as he gives up smoking, reduces his alcohol consumption and stops having affairs. 
so much. Successful in business - freed up by U.S. in this regard" (9.5). Gillian's position in the trio remains ambivalent and her last interaction with Stuart, which she relates in varying ways as analysed by Hamilton (186-88) - "I'm fucking Stuart" (2000, 216), "he fucked me" $(2000,228)$, "When we were making love - no, when he was raping me - no, let's say when we were having sex" $(2000,242)$ - echoes the ambiguity of her staging a quarrel with Oliver at the end of Talking It Over. While several critics found fault with Barnes's characterisation of Gillian as an object of exchange between the two male protagonists, his archives reveal that he considered Gillian as the "prime mover".

\section{Gillian as a Passive Object or the "Prime Mover"?}

Several critics who analysed Talking It Over challenged the patriarchal discourse and the reduction of women to passive objects. Richard Todd draws attention to the way Stuart's ex-girlfriend Val is expelled from the story (1991a, 218-19) so that "one particular feminine voice or discourse is effectively silenced," and he wonders whether Gillian, though able to talk, is not "becoming an object of desire and nothing more, incapable of sustaining the politics of her gender" (Todd 276). Erica Hateley argues that the triangulated affair illustrates "the subordination of female autonomy to male authoritarianism," reasserting "traditional patriarchal ideals of feminine silence, passivity and objectification" and adds that Gillian has been "reduced to an object of competitive ownership," a marketable item, an interpretation shared by Pateman (57) and based on Sedgwick's theory about the patriarchal reliance of women as "objects of exchange" (Sedgwick 26). Merritt Moseley offers a more nuanced interpretation as he argues that Gillian, for all her reticence and quietness, may be the most cunning of the three and the real manipulator: "if readers 'sympathize' with Gillian, Val is right: she has worked her trick on them" $(1997,139)$. Charles Nicholl also argues that Gillian's cautious voice proves to be "the most powerful, even the most exploitative" (19) and John Bayley wonders whether Gillian is "the strong one and the two men her pets and instruments" or "their victim" (26). Such differing viewpoints suggest that the distribution of power in the triangular relationship may be more complex than it appears at first reading, all the more as it depends on the degree of reliability the reader grants each speaker. An examination of the writer's archives reveals that Barnes gave due consideration to Gillian's role and weight in the trio.

The first item on a handwritten page with the title "Things to decide / get right" is "Gillian's voice - is she being squeezed by the other voices?" (14.5). Barnes was well aware of this risk as he pointed out in an interview: "at a certain point I was worried that the woman's voice was being drowned out". To make sure this would not happen, he deliberately deconstructed his careful alternation of monologues: "I simply took all the pages out and read her story as her story all the way through," a process which was facilitated by his using "an old-fashioned typewriter": "it's good to feel the novel physically coming 
apart like that and then laying it back in place" (in Guignery and Roberts 2930). The novelist adopted the same technique of deconstruction and reconstruction of his own text when he read through the parts of Geoffrey Braithwaite's story disseminated in Flaubert's Parrot (1984) and extracted the sections dealing with Martha Cochrane's personal life in England, England (1998), to see, in both cases, if they made a narrative.

An essential dimension of Gillian's character, which is recurrently recorded in Barnes's notes, is the fact that although she may appear unassuming and diffident at first, she is actually the (invisible) prime mover and organiser as suggested by the last scene of Talking It Over, which shows Oliver hit her in the street and which she staged to make sure Stuart would leave them alone (1991a, 267-68). Ten years later in Love, etc., Gillian confesses: "I engineered a scene which I thought would set Stuart free," "I arranged this scene in the street" $(2000,246)$, and Barnes wrote in his notes for the sequel: "G must be visible mover - unlike in TIO" (9.5, my emphasis). For Talking It Over, his handwritten notes on different pages included many indications of Gillian's manipulating skills:

her theory of managing the sitch [situation] as far as that's possible [...] happiness strikes, \& then it has to be managed

she's an organiser

She organises the divorce / remarriage - vicar problem

Both S\& $O$ are in a way handled by her / managed / undone

The alternative theory must be put clearly - that G has organised it all managed it all - that she isn't a girl who's given in to 2 different men \& is acted upon but is herself the/a prime mover

G could show proof of her talent to manipulate a sitch [situation] as at end e.g. she fixes church wedding by getting round vicar

G: some things happen, the rest you have to arrange/manage (14.5)

It is interesting to note the choice of the verbs "manage," "arrange," "fix," "manipulate" and "organise," which are also used by Gillian in the novel. Although Stuart remarks that when pushing the defective trolley at the airport, Gillian "couldn't manage curves on her own" $(1991 \mathrm{a}, 68)$ and, when she falls in love with Oliver, she protests "I didn't choose what happened, I didn't manipulate things" (1991a, 177), she actually proves to be very much in charge, maybe because she remembers the advice of a friend's mother to her daughter just before the wedding: "Mothers telling daughters how to manage their husbands" (1991a, 99). When married to Oliver, Gillian echoes Barnes's notes when she forcefully declares: "You can't just 'be happy'; you have to manage happiness" (1991a, 253), even if she has to confess only two pages later: "I hadn't succeeded in managing happiness" (1991a, 255). At the end of the novel, when she needs to make Stuart leave their village, she takes charge, as suggested by the choice of verbs, and by the steady determination of the ternary rhythm and the italics for the first-person personal pronoun in the first quotation: "I've got to do it, arrange it, fix it" (1991a, 265), "I just have to get on with it. Arrange things for Stuart" (1991a, 266). "I can manage things, that's 
what I'm good at" (1991a, 268). ${ }^{13}$ Stuart and Oliver's former friend Val had told the reader she could see through Gillian's "trick[s]" (1991a, 188): "The quiet sensible ones who claim that things 'just happen' to them are the real manipulators" (1991a, 187). In his notes during the composition of Love, etc., Barnes summed up the content of one of Gillian's monologues as "The answers to her question about 'managing' Oliver" (9.5) and in an early draft for the first chapter of the sequel, Barnes had Oliver declare: "You know, I always believed, deep down, that it was Gill who ran the whole show," and Stuart was "inclined to agree with Oliver" (9.6). These cues were deleted but in the published novel, Oliver becomes aware of Gillian's powerful role - "Certainly been manipulating $m e$ all these years" - and includes the narratee as one of the potential victims of such behaviour: "Point is - question is - how much has she been manipulating you as well?" $(2000,239)$.

In order to reinforce the sense of Gillian being the prime mover, Barnes modified a passage when she protests: "I didn't choose what happened. [...] It just happened" (1991a, 177). The original draft added a self-reflexive comment by Gillian on that formulation: “No, that's too feeble, too passive. It doesn't feel passive when you fall in love, especially with someone like Oliver" (14.6). Hermione Lee was not convinced by Gillian's self-correction and noted: "But all the same she does feel feeble and passive to me. (I know she won't be eventually)," which led Barnes to wonder about the relevance of this passage: "G on her love - 'feeble \& passive'?" (14.5). He decided to delete the comment, thus making sure the two disparaging adjectives would not be associated with Gillian. Such indications from the archives do not discredit the validity of critics' remarks about the patriarchal bias of the diptych but offer an insight into the author's meticulous creative process and the extent to which specific words were meant to encapsulate the specificities of a character's personality and functional significance.

In 1992, the French critic Louis Hay wrote: "Manuscripts have something new to tell us: it is high time we learned to make them speak" $(1992,207)$. Barnes's archives relating to Talking It Over and Love, etc. reveal to what extent the writer carefully constructed his characters both individually and in relation to each other. Although each protagonist was given specific traits and voices, they were also portrayed as complex individuals with room for evolution and transformation. The open endings of two novels (partly due to the absence of any authorial arbitration among the different accounts) point to the author's wish not to impose a unique and final interpretation, thereby also leaving open the possibility for a sequel to the sequel. In a notebook which includes the

13 Gillian echoes this formulation at the beginning of Love, etc. - "My other calculation was that Oliver and I would get through it, that I could manage things. That's what I'm good at, after all." $(2000,19)$ - but admits that things went wrong. Later on, she declares: "You could say I'm managing love. You organise a marriage, you protect your children, you manage love, you run your life" $(2000,159)$, but the stability and certainty of such anaphoric statements are immediately undermined by her doubts as to their exactitude. Kathleen Kelly argues that “Gillian's compulsion to 'manage' love [...] seems to require her to sabotage what she so carefully managed, perhaps in order to escape being trapped by her own management" (189). 
handwritten draft for The Sense of an Ending (2011), Barnes wrote down a list of ideas for future books, which includes "TIO 3".14 No doubt this third volume, if it ever gets written, will further demonstrate Barnes's attentiveness to the intricacies of characterisation.

\section{Works Cited}

Bakhtin, Mikhail. The Dialogic Imagination, edited by Michael Holquist, translated by Caryl Emerson and Michael Holquist. U of Texas P, 1981.

Barnes, Julian. "Diary. Ambushed in Streets of the Sneaky Pun." Guardian 17 June 1989.

---. Talking It Over. 1991a. Picador, 1992.

--.. "U." Hockney's Alphabet, edited by Stephen Spender with drawings by David Hockney. Faber \& Faber, 1991b, unpaginated.

---. Letters from London 1990-1995. Picador, 1995.

--.. “'Merci de m'avoir trahi'." Nouvel Observateur 1675 (12 December 1996), p.114.

--.. Love, etc. Jonathan Cape, 2000.

---. "The Case of Inspector Campbell's Red Hair." The Anthology of New Writing, Volume 15, edited by Maggie Gee and Bernardine Evaristo, Granta Books, 2007, pp.289-99.

Bayley, John. "Getting to Know You." New York Review of Books 5 Dec. 1991: 25-26.

Berlatsky, Eric. "Madame Bovary, c'est moi!': Julian Barnes's 'Flaubert's Parrot" and Sexual 'Perversion'." Twentieth Century Literature, vol. 55, no. 2, Summer 2009, pp.175-208.

Buchan, James. "An Unsuccessful Likeness." Spectator 20 July 1991: 25-26.

Childs, Peter. Julian Barnes. Manchester UP, 2011.

Cooke, Rachel. "Julian Barnes: 'Flaubert could have written a great novel about contemporary America'." Guardian 29 January 2018, https://www.theguardian.com/books/2018/jan/29/julian-barnes-interviewthe-only-story. Accessed 26 April 2020.

Depmann, Jed, Daniel Ferrer and Michael Groden, ed. Genetic Criticism: Texts and Avant-Textes. U of Pennsylvania P, 2004.

Girard, René. Deceit, Desire and the Novel: Self and Other in Literary Structure. Translated by Yvonne Freccero. Johns Hopkins UP, 1972.

Guignery, Vanessa. The Fiction of Julian Barnes. Palgrave Macmillan, 2006.

---. Julian Barnes from the Margins: Exploring the Writer's Archives. Bloomsbury, 2020.

Guignery, Vanessa and Ryan Roberts, eds. Conversations with Julian Barnes. U of Mississippi P, 2009.

Hamilton, Craig. "La narration bakhtinienne dans Talking It Over et Love, etc. de Julian Barnes." Imaginaires, vol. 10, 2004, pp.177-92.

Hateley, Erica. "Erotic Triangles in Amis and Barnes: Negotiations of Patriarchal Power." Lateral: a Journal of Textual and Cultural Studies, vol. 3, 2001. https://eprints.qut.edu.au/27266/1/c27266.pdf. Accessed 26 April 2020.

Hay, Louis. "History or Genesis?" Translated by Ingrid Wassenaar. Drafts, Special issue of Yale French Studies, vol. 89, 1996, pp.191-207. Originally "Histoire ou genèse?" Les Leçons du manuscrit, Special issue of Études françaises, vol. 28, no. 1, 1992, pp.11-27.

---. La littérature des écrivains. Questions de critique génétique. José Corti, 2002.

14 This notebook is included in the as-yet-uncatalogued third acquisition of Barnes's papers. 
Heller, Zoe. "The Square and the Other Two Sides." Independent on Sunday 14 July 1991: SR28.

Holmes, Frederick M. Julian Barnes. Palgrave Macmillan, 2008.

Imlah, Mick. "Giving the Authorized Version." Times Literary Supplement 4606 (12 July 1991): 19.

Jouve, Vincent. L'Effet-personnage dans le roman. Presses Universitaires de France, 1992.

Kelly, Kathleen A. "Humors, Neuroses, and Falling in Love in Julian Barnes's Talking It Over and Love, etc." The International Journal of the Humanities, vol. 9, no. 9, 2012, pp.179-92.

McInerney, Jay. “Julian Barnes and Jay McInerney." 7 March 2001, New York Public Library. Unpublished.

Moseley, Merritt. Understanding Julian Barnes. U of South Carolina P, 1997.

---. "Crossing the Channel: Europe and the Three Uses of France in Julian Barnes's Talking It Over." Julian Barnes, edited by Sebastian Groes and Sean Matthews, Continuum, 2011, pp.69-80.

---. "Julian Barnes and the Contemporary English Sequel." Prequels, Coquels and Sequels in Contemporary Anglophone Fiction, edited by Armelle Parey, Routledge, 2019, pp.128-141.

Nicholl, Charles. “Oliver's Riffs.” London Review of Books 13.14 (25 July 1991): 19.

Pateman, Matthew. Julian Barnes. Northcote House, 2002.

Sedgwick, Eve Kosofsky. Between Men: English Literature and Male Homosocial Desire. Columbia UP, 1985.

Taylor, D. J. "Fearful Symmetry." New Statesman and Society 19 July 1991: 35.

Todd, Richard. "Domestic Performance: Julian Barnes and the Love Triangle." Consuming Fictions. The Booker Prize and Fiction in Britain Today, Bloomsbury, 1996, pp.260-280.

Valera Bravo, Eduardo José. "Faulty Logic and Love Affairs: A Pragmatic Interpretation of a Passage from Julian Barnes's Talking It Over." Atlantis, vol. 18, no.1-2, June-December 1996, pp.416-432.

Watt, Ian. The Rise of the Novel. Studies in Defoe, Richardson and Fielding. U of California P, 1965.

Wood, James. “Bedizened by Baggage.” Guardian 4 July 1991: 26. 